\title{
AKUNTABILITAS PENGELOLAAN KEUANGAN DESA DI NAGARI SICINCIN KECAMATAN 2X11 ENAM LINGKUNG KABUPATEN PADANG PARIAMAN
}

\section{ACCOUNTABILITY OF NAGARI FINANCIAL MANAGEMENT IN SICINCIN 2X11 ENAM LINGKUNG PADANG PARIAMAN}

\author{
Nita Fitria, Nofrivul, dan Rusdi Saputra \\ Fakultas Ekonomi dan Bisnis Islam IAIN Batusangar \\ Jl. Sudirman No. 137, Kuburajo, Lima Kaum, Batusangkar \\ nitafitria1183@gmail.com
}

Naskah diterima 28 Mei 2019, di-review 27 Juni 2019, disetujui 29 Juni 2019

\begin{abstract}
This paper aims to study the accountability of Nagari financial management in Sicincin, $2 X 11$ Enam Lingkung, Padang Pariaman regency in 2017. This type of research is Field Research with descriptive method. Data collection techniques in this research used interviews and collection of documents. The results showed that the government of 2X11 Enam Lingkung Nagari Sicincin of Padang Pariaman Regency had applied the principles of accountability in the management of Nagari finance in 2017. In general, accountability had begun to be implemented. However, there are still some indicators of accountability criteria that have not been implemented by the government of Nagari Sicincin.
\end{abstract}

Keywords: Accountability, Nagari, Financial Management

\begin{abstract}
Abstrak: Penelitian ini bertujuan untuk mengetahui Akuntabilitas Pengelolaan Keuangan Desa di Nagari Sicincin Kecamatan 2X11 Enam Lingkung Kabupaten Padang Pariaman Tahun 2017. Jenis Penelitian ini adalah Field Research atau penelitian lapangan. Metode dalam penelitian ini adalah deskriptif dan menggunakan pendekatan kualitatif. Teknik pengumpulan data dalam penelitian ini adalah menggunakan wawancara dan pengumpulan dokumen-dokumen. Hasil penelitian menunjukkan bahwa pemerintah Nagari Sicincin Kecamatan 2X11 Enam Lingkung Kabupaten Padang Pariaman telah menerapkan prinsip-prinsip akuntabilitas pada pengelolaan keuangan nagari tahun 2017. Secara umum, akuntabilitas sudah mulai diterapkan. Namun, masih ada beberapa indikator dari kriteria akuntabilitas yang belum diterapkan oleh pemerintah Nagari Sicincin
\end{abstract}

Kata Kunci: Akuntabilitas, Pengelolaan Keuangan Nagari

\section{PENDAHULUAN}

A kuntansi merupakan salah satu ilmu yang berkembang dengan pesat, khususnya dalam bidang akuntansi pemerintahan. Akuntansi pemerintahan adalah salah satu bidang ilmu akuntansi yang mengkhususkan dalam pencatatan dan pelaporan transaksi-transaksi yang terjadi di badan pemerintahan. Menurut Bachtiar Arif dkk "Mendefinisikan akuntansi pemerintahan sebagai suatu aktifitas pemberian jasa untuk menyediakan informasi keuangan pemerintah berdasarkan proses pencatatan, pengklasifikasian, pengikhtisaran suatu transaksi keuangan pemerintah serta penafsiran atas informasi keuangan tersebut" (Bachtiar Arif, 2002:3).

Seiring perkembangan zaman akuntansi pemerintahan berkembang dengan pesat. Standar akuntansi pemerintahan dalam Peraturan Pemerintah Republik Indonesia No. 71 Tahun 2010 menjelaskan "Akuntansi pemerintah tidak hanya diterapkan di pemerintahan pusat saja, namun juga ditingkat daerah sampai 
di wilayah perdesaan, secara substansial, terdapat tiga lingkup pemerintahan dalam sistem pemerintahan Republik Indonesia, yaitu pemerintahan pusat, pemerintahan provinsi, dan pemerintahan kabupaten/kota yang semuanya itu membutuhkan pertanggung jawaban disetiap anggaran dan kegiatan yang dilaksanakan" (Peraturan Pemerintah Republik Indonesia No. 71 Tahun 2010, 2010:14).

Pendanaan dari setiap kegiatan pembangunan desa, memerlukan biaya yang terbilang tidak sedikit. Dalam Undang-Undang No. 6 Tahun 2014 dijelaskan desa mendapatkan kucuran dana sebesar 10\% dari APBN. Guna menghindari kecurangan masyarakat harus mengetahui konsep dasar akuntabilitas agar tidak adanya sikap apatis dalam menjalankan segala sesuatu mulai dari perencanaan, pengelolaan hingga pertanggung jawaban. Konsep dasar akuntabilitas didasarkan pada klasifikasi responsibilitas manajerial pada tiap lingkungan dalam organisasi yang bertujuan untuk pelaksanaan kegiatan pada tiap bagian. Masing-masing individu pada tiap jajaran aparatur bertanggung jawab atas setiap kegiatan yang dilaksanakan pada bagiannya.

Anggaran Pendapatan Belanja Negara Perubahan (APBN-P) 2016 telah dialokasikan dana desa sebesar \pm Rp 46, 982 triliun kepada seluruh desa yang tersebar di Indonesia. Jumlah desa yang ada pada tahun 2016 sebanyak 74.754 desa. Nagari Sicincin adalah salah satu nagari yang menerima anggaran pendapatan dari pemerintah yang bersumber dari APBN dan APBD.

Rencana Kerja Pemerintah Desa (RKPDesa) dalam pengelolaan keuangan desa di Nagari

$46 \mid$ | Nita Fitria, Nofrivul, dan Rusdi Saputra
Sicincin dimulai dari; Perencanaan, yaitu penyusunan Rencana Kegiatan Pemerintah Nagari (RKPNag) oleh aparatur nagari dan masyarakat melalui kegiatan Musyawarah Rencana Pembangunan (Musrenbang) untuk merumuskan pembangunan yang akan dilakukan dalam masa 1 tahun anggaran; Pelaksanaan, yaitu wali nagari membentuk Tim Pelaksana Kegiatan (TPK) atau dengan menunjuk salah seorang aparatur nagari untuk menjadi penanggung jawab pada setiap bidang pelaksanaan kegiatan dan dalam hal pelaksanaan ini, lingkungan masyarakatlah yang menjadi TPK utama; Penatausahaan, yaitu Tim Pelaksana Kegiatan (TPK) melaporkan laporan realisasi atas penggunaan dana ke Pelaksana Teknis Pengelolaan Keuangan Nagari (PTPKN) dalam hal ini adalah bendahara nagari; Pelaporan, yaitu wali nagari menyampaikan laporan realisasi pelaksanaan APBDesa kepada bupati per-semester yang diserahkan melalui Badan Keuangan Daerah (BAKEUDA); Pertanggungjawaban, yaitu wali nagari menyampaikan laporan pertanggungjawaban realisasi pelaksanaan APBDesa kepada bupati melalui camat setiap akhir tahun anggaran.

Dari laporan realisasi anggaran pendapatan dan belanja Nagari Sicincin dapat dilihat bahwa, Anggaran Pendapatan Nagari Sicincin tahun 2017 adalah sebesar Rp. 1.808.982.784 dan realisasinya sebesar Rp. 1.804.557.449.- Bantuan keuangan dari APBD provinsi dana yang diterima oleh pemerintahan nagari ternyata tidak terealisasi sebesar yang dianggarkan yaitu Rp. 12.000.000.bagian dari hasil pajak daerah dan retribusi daerah ternyata realisasinya melebihi dari yang dianggarkan sebesar Rp. 39.769.685, terealisasi 
sebesar Rp. 47.367.214.- sehingga mengalami kelebihan dari yang di anggarkan sebesar Rp. 7.597.529.- dari yang dianggarkan.

Jumlah belanja yang dianggarkan tahun 2017 sebesar Rp. 2.005.887.666.- sedangkan realisasinya sebesar Rp. 1.819.483.857.- sehingga memperoleh selisih Rp. 186.403.809.- Selisih ini disebabkan oleh: belanja pegawai yang dianggarkan sebesar Rp. 304.039.200,. terealisasi Rp. 288.139.200.- selisih Rp. 15.900.000, belanja barang dan jasa yang dianggarkan sebesar $\mathrm{Rp}$ 617.881.063.- terealisasi Rp. 535.694.112.selisih Rp. 82.166.951, dan belanja modal yang dianggarkan sebesar Rp. 1.083.967.403.terealisasi Rp. 995.650.545.- selisih Rp. 88.316.858.- Jadi, kelebihan penggunaan dari yang dianggarkan pada tahun 2017 sebesar Rp 181.978.474.

APB Nagari pada tahun 2017 sedikit mengalami penurunan dari tahun sebelumnya. Pendapatan terbesar nagari berasal dari Alokasi Dana Nagari (ADN). Dengan besarnya dana ADN ini tentu semakin tinggi keterbukaan dan tanggung jawab pemerintah nagari dalam pengelolaan Alokasi Dana Nagari (ADN) dan APB Nagari, maka sangat diperlukan akuntabilitas dalam merealisasikan keuangan desa dan dibutuhkan pengalokasian secara transaparansi dari pemerintah nagari sehingga diperlukan peran dari perangkat nagari untuk membantu wali nagari dalam mengelola APB Nagari.

Nagari Sicincin menggunakan Anggaran Pendapatan dan Belanja Desa (APBDesa) yang diberikan Pemerintah melalui APBN, APBD Provinsi, dan APBD Kabupaten pada tahun 2017.
Permasalahan yang terjadi dari pengelolaan keuangan desa di Nagari Sicincin adalah saat pelaksanaan pekerjaan dilapangan, Pelaksana Teknis Pengelola Keuangan Nagari (PTPKN) tidak membuat papan informasi mengenai kegiatan yang sedang berjalan dan laporan realisasi pelaksanaan APBDesa belum dipublikasikan kepada masyarakat". (H. Nurkhalis, Senin pukul 09.00 Wib tanggal 20 Maret 2018 di kantor Wali Nagari Sicincin)

Berdasarkan wawancara tersebut, Pemerintah Nagari Sicincin tidak membuat papan informasi mengenai kegiatan yang sedang berjalan dan laporan realisasi pelaksanaan kegiatan belum dipublikasikan kepada masyarakat. Sedangkan salah satu bentuk pelaksanaan akuntabilitas oleh pemerintah adalah dengan mempublikasikan pengelolaan keuangan nagari kepada masyarakat melalui media informasi yang mudah diakses oleh masyarakat sebagaimana tercantum dalam permendagri nomor 113 tahun 2014 Bab V pasal 40 ayat 1 dan 2 . Oleh karena itu penulis menganggap perlu ada sebuah penelitian lebih lanjut yang dapat memberi solusi terhadap permasalahan yang ada.

Hal ini diharapkan dapat mengurangi kekhawatiran terjadinya ketidakcakapan yang berpotensi menimbulkan salah kelola dana desa yang diragukan banyak pihak selama ini, yaitu mencegah aparatur desa agar tidak berurusan dengan penegak hukum dan untuk menciptakan pemerintahan yang baik (good governance) dalam pengelolaan keuangan desa.

Beberapa fenomena di atas memunculkan pertanyaan yang menarik untuk ditemukan 
JURNAL IMARA

jawabannya. Bagaimana akuntabilitas dalam pengelolaan keuangan Nagari Sicincin?

\section{Kerangka Konseptual}

\section{Pengertian Akuntabilitas}

Mahmudi (2015:9) mendefinisikan Akuntabilitas publik adalah kewajiban agen untuk mengelola sumber daya, melaporkan, dan mengungkapkan segala aktivitas dan kegiatan yang berkaitan dengan penggunaan sumber daya publik kepada pihak pemberi mandat (principal). Dalam konteks organisasi pemerintah, akuntabilitas publik adalah pemberian informasi atas aktivitas dan kinerja pemerintah kepada pihak-pihak yang berkepentingan. Akuntabilitas adalah hal yang penting untuk menjamin nilai seperti efisiensi, efektifitas, reliabilitas dan prediktibilitas. Suatu akuntabilitas tidak abstrak tapi kongkrit dan harus ditentukan oleh hukum melalui seperangkat prosedur yang sangat spesifik mengenai masalah apa saja yang akan dipertanggungjawabkan

\section{Akuntabilitas Perspektif Syariah}

Akuntabilitas dalam perspektif syariah terdapat pada Alquran surat An-Nisa' ayat 58 sebagai berikut:

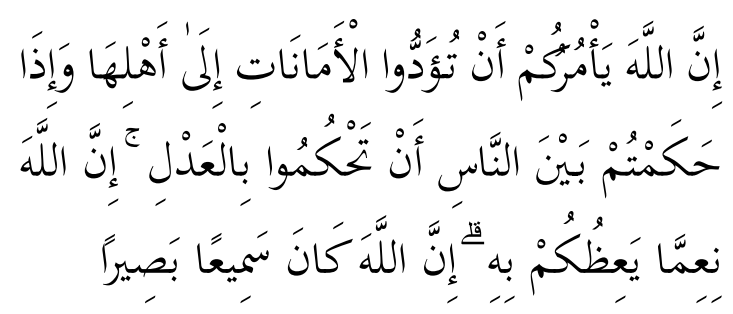

Sesungguhnya Allah menyuruh kamu menyampaikan amanat kepada yang berhak menerimanya, dan (menyuruh kamu) apabila menetapkan hukum di antara manusia supaya kamu menetapkan dengan adil. Sesungguhnya Allah memberi pengajaran yang sebaik-baiknya kepadamu. Sesungguhnya Allah adalah Maha mendengar lagi Maha Melihat.

Akuntabilitas secara umum yaitu pertanggung jawaban antara pemerintah desa kepada bupati/ wali kota dan masyarakat desa atas amanah yang dikuasakan kepadanya. Akuntabilitas perwujudan kewajiban untuk mempertanggung jawabkan pengelolaan dan pengendalian sumber daya dan pelaksanaan kebijakan yang dipercayakan dalam rangka pencapaian tujuan yang telah di tetapkan azas akuntabel yang menentukan bahwa setiap kegiatan dan hasil akhir kegiatan penyelenggaraan pemerintahan desa harus dapat dipertanggungjawabkan kepada masyarakat desa sesuai dengan ketentuan peraturan perundangundangan. (Mardiasmo, 2009:22)

\section{Tolak Ukur Akuntabilitas}

Menurut Sulistoni (2003:35) pemerintahan yang accountable memiliki kriteria sebagai berikut:

a. Mampu menyajikan informasi penyelenggaraan pemerintah secara terbuka, cepat, dan tepat kepada masyarakat,

b. Mampu memberikan pelayanan yang memuaskan bagi publik,

c. Mampu memberikan ruang bagi masyarakat untuk terlibat dalam proses pembangunan dan pemerintahan,

d. Mampu menjelaskan dan mempertanggung jawabkan setiap kebijakan publik secara proporsional, dan

e. Adanyasarana bagipublikuntukmenilaikinerja pemerintah. Melalui penanggungjawaban publik, masyarakat dapat menilai derajat

48 | Nita Fitria, Nofrivul, dan Rusdi Saputra 
pencapaian pelaksanaan program dan kegiatan pemerintah.

Indikator dari kriteria akuntabilitas tersebut adalah sebagai berikut:

a. Mampu menyajikan informasi penyelenggaraan pemerintah secara terbuka, cepat, dan tepat kepada masyarakat

1) Pemerintah desa menyajikan informasi penyelenggaraan pemerintah berdasarkan peraturan perundang-undangan yang berlaku.

2) Menyampaikan laporan realisasi pelaksanaan APBDes kepada bupati/ wali kota berupa:

a) Laporan semester pertama disampaikan paling lambat pada akhir bulan Juli tahun berjalan

b) Laporan semester akhir tahun disampaikan paling lambat pada akhir tahun bulan Januari tahun berikutnya.

3) Pemerintah desa menyampaikan laporan realisasi anggaran kepada bupati/wali kota paling lambat 1 (satu) bulan setelah masa anggaran berakhir

b. Mampu memberikan pelayanan yang memuaskan bagi publik. Pemerintahan yang baik harus memenuhi kualitas pelayanan agar pelayanan tersebut memuaskan bagi publik, terdiri dari:

c. Mampu memberikan ruang bagi masyarakat untuk terlibat dalam proses pembangunan dan pemerintahan (Sujarweni, 2016:37) diantaranya:
1) Masyarakat terlibat dalam rapat dengar pendapatatau rapat paripurna pembahasan dan penetapan anggaran desa

2) Masyarakat memberikan masukan mengenai proses pembangunan desa kepada BPD dan pemerintah desa melalui rapat.

3) Masyarakat ikut serta menjadi panitia pelaksanaan pembangunan nagari

d. Mampu menjelaskan dan mempertanggung jawabkan setiap kebijakan publik secara proporsional. Maksudnya pemerintah nagari menyampaikan laporan realisasi pelaksanaan APBDesa kepada masyarakat desa dan BPD melalui rapat. Pemerintahan nagari dapat mempertanggungjawabkan setiap kebijakan-kebijakan anggaran yang diambil dan menjelaskan kepada masyarakat mengenai dampak kebijakan anggaran tersebut dimasa yang akan datang.

e. Adanya sarana bagi publik untukmenilai kinerja pemerintah. Melalui pertanggungjawaban publik, masyarakat dapat menilai derajat pencapaian pelaksanaan program dan kegiatan pemerintah. Memberikan sarana berupa kotak saran, penyebaran angket dan sarana lainnya untuk menilai kinerja pemerintah nagari.

\section{Pengertian Desa}

Undang-Undang No. 6 Tahun 2014 menyatakan desa adalah desa dan desa adat yang disebut dengan nama lain, selanjutnya disebut desa, adalah kesatuan masyarakat hukum yang memiliki batas wilayah yang berwenang untuk 
mengatur dan mengurus urusan pemerintah, kepentingan masyarakat setempat berdasarkan prakarsa masyarakat, hak asal usul, dan/atau hak tradisional yang diakui dan dihormati dalam sistem pemerintahan Negara Kesatuan Republik Indonesia.

\section{Dana Desa}

Dana desa menurut UU No. 60 Tahun 2014 adalah dana yang bersumber dari Anggaran Pendapatan dan Belanja Negara (APBN) yang diperuntukkan bagi desa yang ditransfer melalui Anggaran Pendapatan dan Belanja Daerah (APBD) kabupaten/kota dan digunakan untuk membiayai penyelenggaraan pemerintah, pelaksanaan pembangunan, pembinaan kemasyarakatan, dan pemberdayaan masyarakat. PP No. 22 Tahun 2015 menyoroti perubahan pengalokasian dana desa yang tercantum dalam Pasal 11, yang mana dana desa setiap kabupaten/kota dihitung berdasarkan jumlah desa dan dialokasikan berdasarkan alokasi dasar dan alokasi yang dihitung dengan memerhatikan jumlah penduduk, angka kemiskinan, luas wilayah, dan tingkat kesulitan geografis desa setiap kabupaten/kota.

\section{Alokasi Dana Desa}

Alokasi Dana Desa (ADD) berdasarkan PP No. 43 Tahun 2014 adalah dana perimbangan yang diterima kabupaten/kota dalam Anggaran Pendapatan dan Belanja Daerah (APBD) kabupaten/kota setelah dikurangi Dana Alokasi Khusus (DAK). PP No. 43 Tahun 2014 menyatakan bahwa pemerintah daerah kabupaten/kota mengalokasikan ADD dalam anggaran pendapatan dan belanja daerah kabupaten/kota untuk setiap tahun anggaran. ADD dialokasikan paling sedikit
$10 \%$ dari dana perimbangan yang diterima kabupaten/kota dalam anggaran pendapatan dan belanja daerah setelah dikurangi dana alokasi khusus. Pengalokasian Alokasi Dana Desa (ADD) mempertimbangkan:

a. Kebutuhan penghasilan tetap kepala desa dan perangkat desa.

b. Jumlah penduduk desa, angka kemiskinan desa, luas wilayah desa, dan tingkat kesulitan geografis desa. Pengalokasian Alokasi Dana Desa (ADD) ditetapkan dengan peraturan bupati/walikota.

\section{Pengelolaan Keuangan Desa}

Menurut Permendagri Nomor 113 Tahun 2014 Bab V bahwa pengelolaan keuangan desa meliputi: perencanaan, pelaksanaan, penatausahaan, pelaporan, dan pertanggungjawaban. Siklus pengelolaan keuangan desa adalah sebagai berikut:

\section{a. Perencanaan}

Mekanisme perencanaan menurut Permendagri Nomor 113 Tahun 2014 adalah sebagai berikut:

1) Sekretaris desa menyusun Rancangan Peraturan Desa tentang APBDesa berdasarkan RKPDesa. Kemudian sekretaris desa menyampaikan kepada kepala desa.

2) Rancangan Peraturan Desa tentang APBDesa disampaikan kepala desa kepada badan permusyawaratan desauntukpembahasan lebih lanjut.

3) Rancangan tersebut kemudian disepakati bersama, dan kesepakatan tersebut paling lama bulan oktober tahun berjalan. 
4) Rancangan peraturan desa tentang APBDesa yang telah disepakati bersama, kemudian disampaikan oleh kepala desa kepada bupati/ walikota melalui camat atau sebutan lain paling lambat tiga hari sejak disepakati untuk dievaluasi. Bupati/walikota dapatmendelegasikan evaluasi rancangan peraturan desa tentang APBDesa kepada camat atau sebutan lain.

5) Bupati/walikota menetapkan hasil evaluasi rancangan APBDesa paling lama 20 hari kerja sejak diterimanya rancangan peraturan

6) Desa tentang APBDesa. Jika dalam waktu 20 hari kerja bupati/ walikota tidak memberikan hasil evaluasi maka peraturan desa tersebut berlaku dengan sendirinya.

7) Jika kepala desa melakukan penyempurnaan paling lama 7 hari kerja terhitung sejak diterimanya hasil evaluasi.

8) Apabila bupati/walikota menyatakan hasil evaluasi rancangan peraturan desa tentang APBDesa tidak sesuai dengan kepentingan umum dan peraturan perundang-undangan yang lebih tinggi, maka kepala desa melakukan penyempurnaan paling lama 7 hari kerja terhitung sejak diterimanya hasil evaluasi.

9) Apabila hasil evaluasi tidak ditindaklanjuti oleh kepala desa dan kepala desa tetap menetapkan rancangan peraturan desa tentang APBDesa menjadi peraturan desa, bupati/walikota membatalkan peraturan desa dengan keputusan bupati/walikota.

10) Pembatalan peraturan desa, sekaligus menyatakan berlakunya pagu APBDesa tahun anggaran sebelumnya. Dalam hal pembatalan, kepala desa hanya dapatmelakukan pengeluaran terhadap operasional penyelenggaraan pemerintah desa.

11) Kepala desa memberhentikan pelaksanaan peraturan desa paling lama 7 hari kerja setelah pembatalan dan selanjutnya kepala desa bersama BPD mencabut peraturan desa dimaksud.

\section{b. Pelaksanaan}

Semua penerimaan dan pengeluaran desa harus didukung oleh bukti yang lengkap dan sah (Sujarweni, 2015: 19). Beberapa aturan dalam pelaksanaan pengelolaan keuangan desa:

1) Pemerintah desa dilarang melakukan pungutan sebagai penerimaan desa selain yang ditetapkan dalam peraturan desa.

2) Bendahara dapat menyimpan uang dalam kas desa pada jumlah tertentu dalam rangka memenuhi kebutuhan operasional pemerintah desa.

3) Pengaturan jumlah uang dalam kas desa ditetapkan dalam peraturan bupati/walikota. Pengeluaran desa yang mengakibatkan beban pada APBDesa tidak dapat dilakukan sebelum rancangan peraturan desa tentang APBDesa ditetapkan menjadi peraturan desa.

4) Pengeluaran desa tidak termasuk untuk belanja pegawai yang bersifat mengikat dan operasional perkantoran yang ditetapkan dalam peraturan kepala desa.

5) Penggunaan biaya tak terduga terlebih dahulu harus dibuat rincian anggaran biaya yang telah disahkan oleh kepala desa.

6) Pengadaan kegiatan yang mengajukan pendanaan untuk melaksanakan kegiatan harus disertai dengan dokumen antara lain rencana anggaran biaya. 
7) Rencana anggaran biaya diverifikasi oleh sekretaris desa dan disahkan oleh kepala desa.

8) Pelaksanakegiatan bertanggungjawabterhadap tindakan pengeluaran yang menyebabkan atas beban anggaran belanja kegiatan dengan mempergunakan buku pembantu kas kegiatan sebagai pertanggungjawaban pelaksanaan kegiatan desa.

9) Pelaksana kegiatan mengajukan Surat Permintaan Pembayaran (SPP) kepada kepala desa. Surat Permintaan Pembayaran (SPP) tidak boleh dilakukan sebelum barang dan atau jasa diterima. Pengajuan SPP terdiri atas Surat Permintaan Pembayaran (SPP), pernyataan tanggungjawab belanja dan lampiran bukti transaksi.

10) Berdasarkan SPP yang diverifikasi sekretaris kepala desa kemudian kepala desa menyetujui permintaan pembayaran dan bendahara melakukan pembayaran.

11) Pembayaran yang telah dilakukan akan dicatat bendahara.

12) Bendahara desa sebagai wajib pungut Pajak Penghasilan (PPh) dan pajak lainnya, wajib menyetorkan seluruh penerimaan potongan dan pajak yang dipungutnya ke rekening kas negara sesuai dengan peraturan perundangundangan.

\section{c. Penatausahaan,}

Berdasarkan Permendagri Nomor 113 Tahun 2014 Bab V Pasal 35, Penatausahaan dilakukan oleh bendahara desa. Bendahara desa wajib melakukan pencatatan setiap penerimaan dan pengeluaran serta melakukan tutup buku setiap akhir bulan secara tertib. Bendahara desa wajib mempertanggung jawabkan uang melalui laporan pertanggung jawaban yang disampaikan setiap bulan kepada kepala desa dan paling lambat tanggal 10 bulan berikutnya.

\section{d. Pelaporan}

Berdasarkan Permendagri Nomor 113 Tahun 2014 Bab V Pasal 37, pelaporan dilakukan oleh kepala desa. Kepala desa menyampaikan laporan realisasi pelaksanaan APBDesa kepada bupati/ walikota berupa laporan semester pertama dan laporan semester akhir tahun. Laporan semester pertama disampaikan paling lambat pada akhir bulan Juli tahun berjalan dan laporan semester akhir tahun disampaikan paling lambat pada akhir bulan Januari tahun berikutnya.

\section{e. Pertanggungjawaban.}

Berdasarkan Permendagri Nomor 113 Tahun 2014 Pasal 38, pertanggungjawaban dilakukan oleh kepala desa. Kepala desa menyampaikan laporan pertanggungjawaban realisasi pelaksanaan APBdesa kepada bupati/ walikota setiap akhir tahun anggaran. Laporan pertanggungjawaban realisasi pelaksanaan APBDesa terdiri dari pendapatan, belanja dan pembiayaan yang ditetapkan dengan peraturan desa.

\section{Kekuasaan Pengelolaan Keuangan Desa}

Permendagri No. 113 Tahun 2014 menjelaskan bahwa kekuasaan pengelolaan keuangan desa berada ditangan kepala desa yang dibantu oleh Pelaksana Teknis Pengelola Keuangan Desa (PTPKD). Kepala desa adalah pemegang kekuasaan pengelolaan keuangan desa dan mewakili pemerintah desa dalam kepemilikan 
kekayaan milik desa yang dipisahkan. Unsur perangkat desa terdiri dari: Sekretaris desa, kepala seksi, dan bendahara

\section{Akuntabilitas dalam Pengelolaan Keuangan Desa}

Bentuk akuntabilitas publik, yaitu:

a. Akuntabilitas hukum dan peraturan (accountability for probility and legality), yaitu terkait dengan jaminan adanya kepatuhan terhadap hukum dan peraturan lain yang disyaratkan dalam penggunaan sumber dana publik.

b. Akuntabilitas proses (process accountability), yaitu terkait dengan apakah prosedur yang digunakan dalam melaksanakan tugas sudah cukup baik. Akuntabilitas proses dalam pemerintah daerah dapat diwujudkan melalui pemberian pelayanan publik yang cepat, responsif, dan murah dari sudut biaya.

c. Akuntabilitas finansial (financial accountability), yaitu pertanggungjawaban lembaga-lembaga publik untuk menggunakan uang publik (public money) secara ekonomi, efisien dan efektif, tidak ada pemborosan dan kebocoran dana serta korupsi.

Pengadaan dilaksanakan dengan prinsip sebagai berikut:

1) Efisien, berarti pengadaan harus diusahakan dengan menggunakan dana dan daya minimum untuk mencapai kualitas dan sasaran dalam waktu yang ditentukan atau menggunakan dana yang telah ditetapkan untuk mencapai hasil dan sasaran dengan kualitas yang maksimum.
2) Efektif, berarti pengadaan harus sesuai dengan kebutuhan dan sasaran yang telah ditetapkan serta memberikan manfaat yang seluas-luasnya.

3) Transparan, berarti semua ketentuan dan informasi mengenai pengadaan bersifat jelas dan dapat diketahui secara luas oleh penyedia barang/jasa yang berminat, serta oleh masyarakat pada umumnya.

4) Terbuka, berarti pengadaan dapat diikuti oleh semua penyedia barang/jasa yang memenuhi persyaratan/kriteria tertentu berdasarkan ketentuan dan prosedur yang jelas.

5) Bersaing, berarti pengadaan harus dilakukan melalui persaingan yang sehat diantara sebanyak mungkin penyedia barang/jasa yang setara dan memenuhi persyaratan sehingga dapat diperoleh barang/jasa yang ditawarkan secara kompetitif dan tidak ada intervensi yang mengganggu terciptanya mekanisme pasar dalam pengadaan.

6) Adil/tidak diskriminatif, berarti memberikan perlakuan yang sama bagi semua calon penyedia barang/jasa dan tidak mengarah untuk keuntungan pihak tertentu dengan tetap mengutamakan kepentingan nasional.

7) Akuntabel, berarti harus sesuai dengan aturan dan ketentuan yang terkait dengan pengadaan sehingga dapat dipertanggungjawabkan.

Akuntabilitas dilihat dari sudut pandang pengendalian merupakan tindakan pada pencapaian tujuan. Pemerintahan yang akuntabel memiliki ciri-ciri sebagai berikut: 
(1) Mampumenyajikaninformasipenyelenggaraan pemerintah secara terbuka, cepat, dan tepat kepada masyarakat.

(2) Mampu memberikan pelayanan yang memuaskan bagi publik.

(3) Mampu memberikan ruang bagi masyarakat untuk terlibat dalam proses pembangunan dan pemerintahan.

(4) Mampu menjelaskan dan mempertanggung jawabkan setiap kebijakan publik secara proporsional.

(5) Adanyasaranabagi publikuntukmenilaikinerja pemerintah. Melalui pertanggungjawaban publik, masyarakat dapat menilai derajat pencapaian pelaksanaan program dan kegiatan pemerintah.

Suatu pemerintahan dikatakan transparan jika memenuhi beberapa kriteria berikut:

(1) Terdapatpengumumankebijakananggaransetiap melakukan kegiatan dengan memperhatikan aspirasi, kebutuhan dan harapan masyarakat.

(2) Tersedia dokumen anggaran dan mudah diakses oleh masyarakat melalui media yang disediakan pemerintah

(3) Tersedia laporan pertanggungjawaban yang tepat waktu yaitu pada akhir bulan Juli tahun berjalan pada semester pertama dan semester kedua paling lambat pada akhir bulan Januari tahun berikutnya sesuai dengan Permendagri No. 113 Tahun 2014.

(4) Terakomodasinya suara/usulan rakyat, yaitu pemerintah desa menerima suara/usulan rakyat dengan memperhatikan aspirasi, kebutuhan, dan harapan masyarakat.

(5) Terdapat sistem pemberian informasi kepada publik, yaitu pemerintah desa memberikan layanan informasi langsung atau tidak langsung mengenai informasi yang berkaitan dengan pemerintah desa, kegiataan dan kinerja pemerintah desa, dan laporan keuangan pemerintah desa menggunakan media surat kabar, surat edaran, dan website.

\section{METODE PENELITIAN}

\section{Jenis Penelitian}

Jenis penelitian ini adalah field research atau penelitian lapangan. Metode yang digunakan dalam penelitian ini adalah deskriptif dengan menggunakan pendekatan kualitatif.

\section{Sumber Data}

Sumber data yang digunakan dalam penelitian ini adalah data primer, Sumber data primer dalam penelitian ini adalah wali nagari, sekretaris nagari dan bendahara nagari dan masyarakat. Kemudian data skunder adalah laporan keuangan Nagari Sicincin Tahun 2017, dan Laporan Realisasi Pelaksanaan Anggaran Pendapatan dan Belanja Desa (APBDesa) Pemerintah Nagari SicincinTahun Anggaran 2017.

\section{Teknik Pengumpulan Data}

Teknik pengumpulan data terdiri dari: wawancara, dokumentasi dan observasi 
Teknik Analisis Data

Standar atau Tolak Ukur Pengelolaan Keuangan Desa Dapat Dikatakan Akuntabel

\begin{tabular}{|c|c|c|}
\hline Variabel & Kriteria & Indikator \\
\hline \multirow{4}{*}{ Akuntabel } & $\begin{array}{l}\text { 1. Mampu menyajikan informasi } \\
\text { penyelenggaraan pemerintah secara } \\
\text { terbuka, cepat, dan tepat. }\end{array}$ & $\begin{array}{l}\text { Pemerintah desa menyajikan/menyerahkan } \\
\text { informasi penyelenggaraan pemerintah desa } \\
\text { berdasarkan Peraturan Perundang-undangan } \\
\text { yang berlaku kepada bupati/walikota dalam } \\
\text { waktu: } \\
\text { 1. Laporan semester pertama } \\
\text { diserahkan paling lambat akhir bulan Juli } \\
\text { tahun berjalan. } \\
\text { 2. Laporan semester kedua diserahkan paling } \\
\text { lambat pada akhir bulan Januari tahun } \\
\text { berikutnya. }\end{array}$ \\
\hline & $\begin{array}{l}\text { 2. Mampu memberikan ruang bagi } \\
\text { masyarakat untuk terlibat dalam proses } \\
\text { pembangunan dan pemerintahan. }\end{array}$ & $\begin{array}{l}\text { 1. Pemerintah desa mengajak dan melibatkan } \\
\text { masyarakat dalam proses pembangunan } \\
\text { desa mulai dari penyusunan rencana } \\
\text { pembangunan desa sampai pelaksanaan } \\
\text { pembangunan desa. } \\
\text { 2. Pemerintah desa menerima usulan/masukan } \\
\text { dari masyarakat saat perumusan program } \\
\text { desa dan penetapan anggaran desa. }\end{array}$ \\
\hline & $\begin{array}{l}\text { 3. Mampu menjelaskan dan } \\
\text { mempertanggungjawabkan setiap } \\
\text { kebijakan publik secara proporsional. }\end{array}$ & $\begin{array}{l}\text { 1. Pemerintah desa mampu menjelaskan } \\
\text { dan mempertanggungjawabkan kebijakan- } \\
\text { kebijakan penggunaan anggaran. } \\
\text { 2. Pemerintah desa menyampaikan dan } \\
\text { menjelaskan laporan pertanggungjawaban } \\
\text { realisasi pelaksanaan APBDesa kepada } \\
\text { masyarakat dan badan permusyawaratan } \\
\text { desa melalui musyawarah evaluasi kinerja } \\
\text { pemerintah desa. }\end{array}$ \\
\hline & $\begin{array}{l}\text { 4. Adanya sarana bagi publik untuk } \\
\text { menilai kinerja pemerintah. }\end{array}$ & $\begin{array}{l}\text { Pemerintah desa menyediakan sarana bagi } \\
\text { masyarakat untuk menilai kinerja pemerintah } \\
\text { desa, diantaranya: } \\
\text { 1. Pemerintah desa menyediakan kotak saran } \\
\text { untuk peningkatan pelayanan publik. } \\
\text { 2. Musyawarah desa sebagai sarana untuk } \\
\text { mengevaluasi kinerja pemerintah desa. }\end{array}$ \\
\hline
\end{tabular}

Sumber: Mardiasmo (2012:68)

PEMBAHASAN DAN HASIL

\section{Akuntabilitas Pengelolaan Keuangan Nagari}

Pemerintahan Nagari Sicincin telah menyampaikan laporan pertanggungjawaban realisasi pelaksanaan APBDesa kepada bupati setiap akhir tahun anggaran, dan laporan pertanggungjawaban yang dimaksud telah terpenuhi seperti yang ditetapkan yang terdiri dari pendapatan, belanja dan pembiayaan yang sekaligus ditetapkan sebagai Peraturan Nagari serta pada peraturan nagari tersebut melampirkan format- format seperti: format laporan pertanggungjawaban realisasi pelaksanaan APBDesa, format laporan kekayaan milik desa dan format laporan program pemerintah yang masuk ke nagari. 
1. Mampu menyajikan penyelenggaraan pemerintahan secara terbuka, cepat dan tepat.

a. Pemerintah Nagari Sicincin menyampaikan laporan pertanggung-jawaban pelaksanaan realisasi anggaran tiap semester kepada Bupati Padang Pariaman.

Nagari Sicincin, sudah menyampaikan laporan pertanggungjawaban pelaksanaan realisasi anggaran tepat waktu kepada bupati yaitu pada bulan Juli tahun berjalan. Laporan semester pertama disampaikan wali nagari kepada BAMUS untuk disetujui, setelah itu disampaikan ke kecamatan dan dilanjutkan disampaikan kepada bupati melalui Dinas Pemberdayaan Masyarakat dan Desa (DPMD) bagian pemerintahan desa.

Nagari Sicincin telah memenuhi kriteria tersebut yaitu tentang kemampuan menyajikan informasi penyelenggaraan pemerintah secara terbuka, cepat dan tepat. Hal ini dibuktikan dengan tepat waktunya dalam menyajikan sekaligus mempertanggungjawabkan realisasi peyelenggaraan pemerintah.

b. Pemerintah nagari menyampaikan laporan pertanggungjawaban pelaksanaan realisasi anggaran kepada bupati paling lambat 1 (satu) bulan setelah masa anggaran berakhir.

Pemerintah Nagari Sicincin telah menyampaikan laporan pertanggungjawaban berupa LPPN kepada Bupati Padang Pariaman paling lambat 1 (satu) bulan setelah masa anggaran berakhir. Pemerintah nagari telah menyampaikan laporan pertanggungjawaban pelaksanaan realisasi anggaran kepada bupati 1 (satu) bulan setelah masa anggaran berakhir, hal ini dibuktikan dengan pengesahan laporan penyelenggaraan pemerintahan nagari pada tanggal 28 Januari 2018 seperti yang terdapat pada lampiran halaman 140 .

\section{Mampu memberikan pelayanan yang memuaskan bagi masyarakat}

a. Pemerintah Nagari Sicincin memberikan pelayanan yang tepat waktu, kenyamanan dalam pelayanan, sopan dan ramah dalam pelayanan, kemudahan dalam proses pelayanan, memberikan pelayanan yang adil dan merespon setiap keluhan masyarakat. Pemerintah Nagari Sicincin telah memberikan pelayanan yang adil kepada masyarakatsesuai dengan apa yang dibutuhkan masyarakat. Ketepatan waktu dalam pelayanan juga relatif cepat dan kemudahan yang diberikan saat pelayanan juga tergantung dengan apa yang di urus masyarakat. Pemerintah Nagari Sicincin juga termasuk ramah dalam memberikan pelayanan dan merespon keluhan masyarakat hal ini dapat dilihat dari pembangunan dan pembaharuan yang dilakukan pemerintah nagari yaitu berdasarkan keluhan, keinginan dan harapan masayarakat, dari beberapa hal baik yang telah dicapai oleh pemerintah nagari, masih terdapat kekurangan seperti menyediakan lingkungan yang nyaman dalam memberikan pelayanan, hal ini yang harus menjadi tanggung jawab pemerintahan nagari untuk menyediakan lingkungan yang nyaman demi tercapainya good and governance di pemerintahan Nagari Sicincin. 
3. Mampu memberikan ruang bagi masyarakat untuk terlibat dalam proses pembangunan dan pemerintahan.

a. Pemerintah Nagari Sicincin melibatkan masyarakat dalam perencanaan pembangunan nagari sampai dengan pelaksanaan pembangunan nagari.

Dalam perencanaan pembangunan, penetapan anggaran sampai pada pelaksanaan pembangunan yang ada di Nagari Sicincin telah melibatkan seluruh lapisan masyarakat mulai dari Badan Permusyawaratan Nagari (BAMUS), Kerapatan Adat Nagari (KAN), Lembaga Unsur dan Tokoh-tokoh masyarakat melalui Musyawarah Rencana Pembangunan (MusrenbangNag) di Nagari dan rapat Rencana Pembangunan Jangka Menengah (RPJM) di korong masing- masing.

Hal ini dibuktikan dengan daftar hadir peserta Musrenbang RKP di Nagari Sicincin tahun 2017 yang terdapat pada lampiran halaman 156-157.

b. Pemerintah Nagari Sicincin menerima usulan/ masukan dari masyarakat saat perumusan program nagari dan penetapan anggaran nagari. Perencanaan anggaran pendapatan dan belanja desa di Nagari Sicincin yang telah ditetapkan adalah dari hasil penyusunan rancangan peraturan nagari tentang anggaran pendapatan dan belanja desa (APBDesa) yang dibuat oleh Wali Nagari atas dasar dari usulan-usulan yang diberikan oleh masyarakat.

Hal ini dibuktikan dengan disahkannya Rencana Kerja Pemerintahan Nagari (RKPNagari) Sicincin oleh BAMUS pada tanggal 23 Januari 2017 seperti yang terdapat pada lampiran halaman 141-148. Dengan ini berarti pemerintahan Nagari Sicncin telah melalui tahapan musyawarah dengan masyarakat sebelum diserahkan untuk pengesahan kepada BAMUS

Daripernyataan tersebut, dapat diketahui bahwa pemerintah Nagari Sicincin sudah menjalankan prinsip partisipatif dalam pengelolaan anggaran keuangan desa, yaitu telah menerima usulan/ masukan dari masyarakat saat perumusan program nagari dan penetapan anggaran nagari.

c. Masyarakat ikut serta menjadi panitia pelaksanaan pembangunan nagari.

Masyarakat ikutserta menjadi panitia pelaksana pembangunan nagari yang disebut dengan TPK (Tim Pelaksana Kegiatan). Masyarakat yang diikut sertakan tersebut, merupakan masyarakat yang telah disepakati dalam musyawarah. Dalam musyawarah tersebut, pemerintah nagari mensosialisasikan kegiatan apa yang akan dilakukan, berapa dananya dan siapa sajakah masyarakat yang menjadi TPK. Hal ini dirumuskan dan ditetapkan saat penyusunan Rencana Kerja Pemerintahan Nagari (RKPNagari) yang tertuang dalam peraturan nagari tentang RKPNagari tahun 2017 yang terdapat pada lampiran halaman 141.

4. Mampu menjelaskan dan mempertanggungjawabkan setiap kebijakan publik secara proporsional.

a. Pemerintah nagari Sicincin menyampaikan laporan pertanggung-jawaban pelaksanaan realisasi dana desa kepada masyarakat desa melalui rapat/ musyawarah nagari. Nagari Sicincin telah menyampaikan laporan 
pertanggungjawaban kepada BAMUS dan masyarakat nagari. Akan tetapi, tidak semua masyarakat nagari yang hadir dalam rapat tersebut hanya saja lembaga-lembaga masyarakat yang menghadirinya. Selain itu kendala lainya yang di hadapi yaitu petugas pelaksana pekerjaan lapangan tidak membuat papan informasi mengenai kegiatan yang sedang berjalan sehingga hal ini tidak terpublikasikan kepada masyarakat luas. Hal ini tentu belum sesuai dengan Permendagri No. 113 tahun 2014 Bab V pasal 40 ayat 1 dan 2 yang mengharuskan di informasikan kepada masyarakat secara tertulis dan dengan media yang mudah di akses oleh masyarakat seperti papan pengumuman, radio komunitas dan media informasi lainya.

Badan Permusyawaratan Nagari atau yang dikenal dengan BAMUS Nagari dilibatkan dalam hal pertanggungjawaban begitu juga dengan hal-hal lain yang menjadi tanggungjawab dari BAMUS.

b. Pemerintah Nagari Sicincin mempertangungjawabkan setiap kebijakankebijakan penggunaan keuangan desa yang diambil dan menjelaskan kepada masyarakat mengenai dampak kebijakan tersebut dimasa yang akan datang. Rancangan penggunaan dana nagari disusun berdasarkan usulan dari masyarakat nagari pada saat pra musyawarah. Jadi, setiap kebijakan yang diambil oleh pemerintah nagari telah dijelaskan kepada masyarakat mengenai dampak kebijakan tersebut dimasa yang akan datang.

58 | Nita Fitria, Nofrinul, dan Rusdi Saputra

\section{Ada sarana bagi publik untuk menilai kinerja pemerintah nagari}

Nagari Sicincin dan juga masyarakat, belum ada sarana untuk penilaian kinerja pemerintahan nagari yang disediakan oleh pemerintah nagari, berupa kotak saran maupun angket. Hanya saja pemerintahan nagari menyediakan wadah penyampaian aspirasi secara langsung dan ketika musyawarah rencana pembangunan nagari. Hal ini tentu belum tepat jika dikaitkan dengan pengertian kinerja dan dimensi yang dapat dijadikan sebagai tolak ukur atau indikator dalam menilai kinerja. Jadi pemerintahan Nagari Sicincin perlu adanya kotak saran atau angket yang diharapkan pemerintahan Nagari Sicincin semakin baik untuk masa masa yang akan datang.

\section{Proses Pengelolaan Keuangan Nagari.}

\section{Perencanaan}

Perencanaan anggaran pendapatan dan belanja nagari di Nagari Sicincin dilakukan oleh wali nagari dengan BAMUS. APBNagari yang ditetapkan oleh wali nagari dan BAMUS merupakan APBNagari yang ditetapkan dari hasil penyusunan rancangan APBNagari yang dibuat oleh wali nagari dengan mendengarkan aspirasi masyarakat nagari. Program pembangunan tahunan desa diturunkan dari program pembangunan jangka menengah desa (lima tahun), yang disebut rencana pembangunan jangkah menengah desa (RPJMDesa).

\section{Pelaksanaan}

Pelaksanaan APBNagari yang ada di Nagari Sicincin dilaksanakan oleh pemerintah Nagari 
Sicincin beserta partisipasi masyarakat dalam pembangunan, pemberdayaan masyarakat dan kemajuan Nagari Sicincin. Masyarakat diikut sertakan menjadi tim pelaksana kegiatan (TPK), masyarakat yang jadi TKP merupakan masyarakat yang telah ditetapkan dalam musyawarah.

\section{Penatausahaan}

Dalam pemerintahan Nagari Sicincin itu yang ada buku kas umum, buku pembantu pajak, dan buku pembantu bank. Buku kas umum ini berfungsi untuk mencatat seluruh penerimaan dan pengeluaran kas di Nagari Sicincin. Pada saat pengeluaran kurang dari Rp 1.000.000, maka akan dikenakan PPN, dan pada saat pengeluaran lebih dari Rp 1.000.000, maka akan dikenakan $\mathrm{PPh}$. Pajak yang dikenakan tersebut harus disetorkan oleh bendahara kepada rekening kas negara. (Lidya Yolanda, Jum'at, 29 Juni 2018 Pukul 14.20 WIB di Kantor Wali Nagari Sicincin).

Bukti yang lengkap dan sah yang digunakan oleh pemerintah nagari yaitu: faktur, kwitansi, Jika belanja lebih dari 50 juta rupiah, maka SPK (Surat Pertanyaan Kerjasama)

Pengelolaan keuangan nagari telah menggunakan sistem keuangan desa (SISKEUDES) mulai dari tahun 2016, SISKEUDES adalah suatu aplikasi keuangan yang dikembangkan oleh BPKP berkerjasama dengan Kementrian Dalam Negeri (Mendagri) dan Kemendesa PDTT untuk digunakan diseluruh Indonesia dalam pengelolaan keuangan desa. Sehingga memudahkan pemerintah desa untuk pencatatan penerimaan dan pengeluaran APB Nagari.

\section{Pelaporan}

Pemerintah Nagari Sicincin telah menyampaikan laporan pertanggungjawaban berupa LPPN kepada Bupati Padang Pariaman secara tepat waktu paling lambat 1 (satu) bulan setelah masa anggaran berakhir.

Laporan semester kedua juga sudah disampaikan tepat waktu kepada bupati melalui camat pada akhir Januari tahun berikutnya. Laporan semester kedua berupa laporan pertanggungjawaban realisasi pelaksanaan anggaran pendapatan dan belanja desa (APBDesa) yang dilampiri: format laporan pertanggungjawaban realisasi pelaksanaan APBDesa tahun anggaran berkenaan, format laporan kekayaan milik desa per 31 Desember tahun anggaran berkenaan dan format laporan program pemerintah dan pemerintah daerah yang masuk ke desa.

\section{Pertanggungjawaban}

Nagari Sicincin sudah membuat laporan penyelenggaraan pemerintah nagari yang didalamnya dimuat laporan pertanggungjawaban realisasi pelaksanaan anggaran pendapatan dan belanja nagari (APBNagari) dan laporan kekayaan milik desa

\section{PENUTUP}

Dari penelitian tersebut dapat disimpulkan bahwa dari segi penyampaian laporan kepada masyarakat, pemerintah nagari telah menyampaikan laporan pertanggungjawaban realisasi pelaksanaan anggaran kepada masyarakat melalui rapat. Dalam penyusunan 
anggaran pada tahap perencanaan, masyarakat diikutsertakan dalam pra musyawarah yang diadakan di setiap korong-korong yang ada di Nagari Sicincin. Namun, masih ada indikator yang belum terpenuhi dari kriteria akuntabel, yaitu belum tersedianya sarana berupa kotak saran atau pengisian angket untuk penilaian kinerja pemerintah nagari. Hal ini tentu belum sesuai dengan Permendagri No. 113 tahun 2014 Bab $V$ pasal 40 ayat 1 dan 2 yang mengharuskan di informasikan kepada masyarakat secara tertulis dan dengan media yang mudah di akses oleh masyarakat. Sedangkan dalam hal proses pengelolaan keuangan nagari, pemerintah Nagari Sicincin sudah menyusun dan mengelola keuangan nagari sesuai dengan aturan yang berlaku. Proses pelaksanaan sesuai dengan aturan Permendagri No. 113 Tahun 2014 yang mana pelaksanaan kegiatan di nagari harus melibatkan masyarakat agar tercapainya tujuan pembangunan yang diinginkan

\section{DAFTAR KEPUSTAKAAN}

Badan Pengawasan Keuangan dan Pembangunan. (2015). Petunjuk Pelaksanaan Bimbingan dan Konsultasi Pengelolaan Keuangan Desa. Deputi Bidang Pengawasan Penyelenggaraan Keuangan Daerah.

Bahtiar Arif, Muchlis, iskandar. (2002). Akuntansi Pemerintahan. Yogyakarta: BPFE

Halim, Abdul. (2007). Akuntansi dan Pengendalian Pengelolaan Keuangan Daerah. UPP STIM YKPN: Yogyakarta.

60|| Nita Fitria, Nofrivul, dan Rusdi Saputra
Halim, Abdul. Kusufi, Syam. (2014). Akuntansi Sektor Publik: Teori, Konsep dan Aplikasi. Salemba Empat: Jakarta.

Haryanto, Sahmuddin. (2007). Akuntansi Sektor Publik, Edisi Pertama. Universitas Diponegoro: Semarang.

Ikatan Akuntansi Indonesia. (2015). Kompartemen ASP; Pedoman Asistensi Akuntansi Keuangan Desa. Jakarta: Salemba Empat

Kementerian Keuangan Republik Indonesia. (2016). Kebijakan Pengalokasian dan Penyaluran Dana Desa Tahun 2017. http:// www.djpk.depkeu.go.id/wp-content/ uploads/2016/11/paparan-kemenkeu.pdf

Mardiasmo. (2009). Akuntansi Sektor Publik. Yogyakarta: Andi Offset.

PERMENDAGRI. (2014). Peraturan Menteri Dalam Negeri Republik Indonesia Nomor 113 Tahun 2014 Tentang Pengelolaan Keuangan Desa. Jakarta.

PERMENDAGRI.(2014). Peraturan Menteri Dalam Negeri Republik Indonesia Nomor 114 Tahun 2014 Tentang Pedoman Pembangunan Desa. Jakarta

Presiden Republik Indonesia. (2010). Peraturan Pemerintah Republik Indonesia Nomor 71 Tahun 2010 tentang Standar Akuntansi Pemerintahan. Jakarta.

Presiden Republik Indonesia. (2014). Undangundang Republik Indonesia Nomor 43 Tahun 2014 Tentang Peraturan Pelaksanaan Undang-Undang Nomor 6 Tahun 2014 Tentang Desa. Jakarta. 
VOLUME 3, NOMOR 1, JUNI 2019

Republik Indonesia. (2014). Undang-undang Republik Indonesia Nomor 23 Tahun 2014 Tentang Pemerintahan Daerah. Jakarta.

Republik Indonesia. (2014). Undang-undang Republik Indonesia Nomor 60 Tahun 2014 Tentang Dana Desa Yang Bersumber Dari Anggaran Pendapatan dan Belanja Negara. Jakarta.

Republik Indonesia. (2014). Undang-undang Republik Indonesia Nomor 6 Tahun 2014 Tentang Desa. Jakarta.
Sugiyono, (2015). Metode Penelitian Pendidikan (Pendekatan Kuantitatif, Kualitatif dan R\&D). CV. Alfabeta: Bandung

Sujarweni, W. (2015). Akuntansi Desa-Panduan Tata Kelola Keuangan Desa, Jakarta: Pustaka Baru Press.

Sulistyani, A.T. (2011). Memahami Good Governance: Dalam Perspektif Sumber Daya Manusia. Gava Media: Yogyakarta. 
